\title{
Pengaruh ASI Eksklusif+MP-ASI terhadap Status Gizi Bayi Usia 6-9 Bulan di Desa Sukawening, Kecamatan Ciwidey Kabupaten Bandung
}

\author{
Alma Tanzia Nasa, ${ }^{1}$ Eka Nurhayati, ${ }^{2}$ Hana Sofia, ${ }^{3}$ Zulmansyah, $^{3}$ Herry Garna ${ }^{3}$ \\ ${ }^{1}$ Program Studi Sarjana Kedokteran, Fakultas Kedokteran Universitas Islam Bandung \\ ${ }^{2}$ Departemen Ilmu Kesehatan Masyarakat, Fakultas Kedokteran Universitas Islam Bandung \\ 3Departemen Ilmu Kesehatan Anak, Fakultas Kedokteran Universitas Islam Bandung
}

\begin{abstract}
Abstrak
Nutrisi merupakan kebutuhan yang sangat penting dalam proses pertumbuhan dan perkembangan bayi. Untuk meningkatkan status gizi agar menurunkan angka kematian anak, United Nations Children's Fund (UNICEF) dan World Health Organization (WHO) merekomendasikan sebaiknya anak diberi air susu ibu (ASI) eksklusif selama 6 bulan, lalu diberi makanan pendamping ASI setelah 6 bulan, dan ASI dilanjutkan sampai usia 2 tahun. Menurut WHO, makanan pendamping air susu ibu (MP-ASI) merupakan sebuah proses penting yang mengedepankan kesiapan bayi dalam menyambut makanan yang akan dikonsumsinya. Tujuan penelitian ini mengetahui pengaruh ASI eksklusif+MP-ASI terhadap status gizi bayi usia $6-9$ bulan. Penelitian ini menggunakan metode observasional analitik dengan pendekatan cohort menggunakan teknik pemilihan sampel cluster random sampling periode Maret-Juni 2018. Pengumpulan data diambil dari hasil pengukuran antropometri berat badan/usia untuk mengetahui status gizi bayi 4 bulan ke depan (bulan ke-6, -7, -8, dan -9). Hasil penelitian menggunakan analisis Uji Fisher Exact dan Kruskal Wallis diperoleh dari 52 sampel. Jumlah kelompok yang diberi ASI eksklusif 27 bayi, sedangkan jumlah kelompok yang diberi ASI noneksklusif 25 bayi. Hasil analisis didapatkan terdapat pengaruh ASI eksklusif+MP-ASI terhadap kenaikan status gizi pada kelompok ASI eksklusif maupun noneksklusif $(\mathrm{p}=0,047)$. Faktor pendidikan ibu, pekerjaan ibu dan sosio ekonomi keluarga terhadap status gizi kelompok ASI eksklusif dan noneksklusif tidak terdapat pengaruh $(\mathrm{p}=0,19 ; \mathrm{p}=0,25 ;$ dan $\mathrm{p}=0,54)$. Kenaikan status gizi kedua kelompok tersebut tiap bulannya mengalami kenaikan yang signifikan. Simpulan, terdapat pengaruh ASI-eksklusif+MP-ASI terhadap status gizi bayi usia 6-9 bulan di Desa Sukawening Kecamatan Ciwidey Kabupaten Bandung.
\end{abstract}

Kata kunci: ASI eksklusif, MP-ASI, status gizi

\section{Effect of Exclusive Breastfeeding+Complementary Food for Breast Milk to Nutritional Status Baby Age 6-9 Month in Sukawening Village, District Ciwidey District Bandung}

\begin{abstract}
Nutrition is a very important requirement in the process of baby growth and development. Improving nutritional status in order to reduce child mortality, the United Nations Children's Fund (UNICEF) and the World Health Organization (WHO) recommend that children be given exclusive breast milk for 6 months, then given complementary breastfeeding after 6 months, and breast milk continued until the age of 2 years. According to WHO, complementary food for breast milk is an important process that prioritizes the readiness of the baby in welcoming the food he will consume. The purpose of this study was to determine the effect of exclusive breastfeeding+complementary food for breast milk on the nutritional status of infants aged 6-9 months. This research used an analytic observational method with a cohort approach using cluster random sampling technique for the period March-June 2018. Data collection was taken from the results of weight / age anthropometry measurements to determine the nutritional status of infants 4 months ahead (-6th -7th, , -8th, and -9th month). The results of the study using Fisher exact and Kruskal Wallis analysis were obtained from 52 samples. The number of groups given exclusive breastfeeding was 27 babies, while the number of groups that were given non-exclusive breastfeeding was 25 babies. The results of the analysis showed that there was an effect of exclusive breastfeeding + complementary food for breast milk on the increase in nutritional status in exclusive and non-exclusive breastfeeding groups $(\mathrm{p}=0.047)$. The factors of maternal education, maternal work and family socioeconomic on the nutritional status of exclusive and nonexclusive breastfeeding groups were not affected $(\mathrm{p}=0.19, \mathrm{p}=0.25$ and $\mathrm{p}=0.54)$. The increase in nutritional status of the two groups each month experienced a significant increase. Conclusions there are the effect of exclusive breastfeeding+complementary food for breast milk on the nutritional status of infants aged 6-9 months in Sukawening Village, Ciwidey District, Bandung Regency.
\end{abstract}

Keywords: Complementary food for breast milk, exclusive breastfeeding, nutritional status 


\section{Pendahuluan}

Nutrisi merupakan kebutuhan yang sangat penting dalam proses pertumbuhan dan perkembangan bayi. Dengan nutrisi, bayi akan terhindar dari berbagai macam penyakit yang diakibatkan oleh gizi buruk dan gizi juga sebagai sumber tenaga, zat pembangun, dan zat pengatur sehingga akan membantu aktivitas sehari-hari. ${ }^{1}$

Untuk meningkatkan status gizi agar menurunkan angka kematian anak, United Nations Children's Fund (UNICEF) dan World Health Organization (WHO) merekomendasikan sebaiknya anak diberi air susu ibu (ASI) eksklusif selama 6 bulan, lalu diberi makanan penunjang ASI setelah 6 bulan, dan ASI dilanjutkan sampai usia 2 tahun. ${ }^{2}$ Air susu ibu adalah makanan terbaik yang dapat diberikan oleh seorang ibu kepada bayinya. Berbagai penelitian telah mengkaji manfaat pemberian ASI eksklusif dalam hal menurunkan mortalitas dan morbiditas bayi. ${ }^{3}$

Di Indonesia masih banyak ibu yang tidak memberikan ASI eksklusif pada bayinya, melainkan menggantinya dengan susu formula di dalam Peraturan Menteri Kesehatan No. 39 Tahun 2013 tentang susu Formula Bayi dan Produk Bayi Lainnya, susu formula ialah susu yang secara khusus diformulasikan sebagai pengganti ASI untuk bayi. Pemberian susu formula pada bayi yang kurang tepat frekuensi, takaran, dan sanitasi penyajiannya akan mengakibatkan masalah gizi, dapat gizi lebih atau gizi kurang. Peningkatan risiko gizi lebih sering pada bayi yang diberikan susu formula daripada yang diberi ASI. ${ }^{3}$ Gizi lebih pada bayi akan menganggu perkembangan anak di antaranya gerak motorik kasar dan gerak motorik halus sehingga bayi tidak dapat melakukan pergerakan yang seharusnya dapat dilakukan pada usia tersebut. ${ }^{4}$

Usia 6 bulan merupakan titik awal masalah gizi kurang yang berkaitan dengan masa peralihan (weaning period) dan diet bayi berubah dari ASI saja ke arah makanan orang dewasa. Menurut WHO, makanan pendamping air susu ibu (MP-ASI) merupakan sebuah proses penting yang mengedepankan kesiapan bayi dalam menyambut makanan yang akan dikonsumsinya. Pemberian MP-ASI yang tepat diharapkan tidak hanya dapat memenuhi kebutuhan gizi bayi, namun juga merangsang keterampilan makan dan merangsang rasa percaya diri pada bayi. ${ }^{5}$ Penelitian ini bertujuan untuk menganalisis hubungan pola pemberian MPASI dengan status gizi anak usia 6-23 bulan. Jenis penelitian observasional analitik dengan desain cross-sectional study. Jumlah populasi adalah semua anak usia 6-23 bulan yang berada di wilayah pesisir Kecamatan Tallo Kota Makassar. Sampel, yaitu semua anak usia 6-23 bulan yang diambil dengan menggunakan teknik exhaustive sampling didapatkan 150 anak. Hasil penelitian menunjukkan hubungan frekuensi pemberian MP-ASI dengan status gizi $(\mathrm{BB} / \mathrm{U})$.

Praktik pemberian MP-ASI dini sebelum usia enam bulan masih banyak dilakukan di negara berkembang seperti Indonesia. Hal ini akan berdampak terhadap kejadian infeksi yang tinggi seperti diare, infeksi saluran napas, alergi, hingga gangguan pertumbuhan. ${ }^{6}$

Hasil penelitian sebelumnya yang dilakukan oleh Ratnaningsih ${ }^{7}$ menunjukkan pengaruh ASI eksklusif dan MP-ASI terhadap status gizi bayi usia 6-12 tahun. Bayi yang mendapat ASI eksklusif dan MP-ASI status gizinya cenderung lebih baik dibanding dengan bayi yang mendapat ASI non eksklusif dan MP-ASI.

Berdasar atas data yang diperoleh dari Puskesmas Rawabogo bahwa di Desa Sukawening, Kecamatan Ciwidey Kabupaten Bandung terdapat permasalahan dalam status gizi. Prevalensi status gizi kurang berdasar atas indikator $\mathrm{BB} / \mathrm{U}$ sebesar $14 \%$ terdiri atas $7 \%$ gizi buruk dan $7 \%$ gizi kurang, sedangkan untuk indikator $\mathrm{TB} / \mathrm{U}$ menunjukkan prevalensi stunting sebesar $66 \%$ terdiri atas $45 \%$ sangat pendek, 20\% pendek, dan $1 \%$ tinggi. Indikator $\mathrm{BB} / \mathrm{TB}$ menunjukkan prevalensi sebesar $11 \%$ terdiri atas $1 \%$ balita yang sangat kurus, $7 \%$ kurus, dan $4 \%$ balita yang gemuk $5 \%$.

Penelitian ini bertujuan mengetahui pengaruh ASI eksklusif+MP-ASI terhadap status gizi dibanding dengan bayi yang mendapat ASI noneksklusif+MPASI bayi berusia $6-9$ bulan di Desa Sukawening, Kecamatan Ciwidey Kabupaten Bandung.

\section{Metode}

Metode penelitian yang digunakan pada penelitian ini berupa observasional analitik dengan pendekatan cohort. Pengamatan terhadap dua kelompok populasi bayi yang diberi ASI eksklusif+MP-ASI dan ASI noneksklusif+MP-ASI dalam jangka waktu 4 bulan ke depan (bulan ke-6, -7, -8, dan -9). Pengumpulan data diambil dari hasil kuesioner dan pengukuran antropometri berat badan/usia pada periode MaretJuni 2018.

Subjek penelitian adalah masyarakat di Desa Sukawening, Kecamatan Ciwidey Kabupaten Bandung yang didapat sesuai dengan penelitian berjumlah 52 bayi dengan 27 bayi mendapat ASI eksklusif dan 25 bayi mendapat ASI noneksklusif dan telah memenuhi kriteria inklusi. Kriteria inklusi bayi yang mendapat ASI eksklusif+MP-ASI adalah bayi yang mendapat ASI saja sampai usia 6 bulan dengan berat badan lahir normal. Kriteria inklusi bayi yang mendapat ASI noneksklusif+MP-ASI adalah bayi yang mendapat susu formula/makanan lain selain ASI sampai usia 6 bulan dengan berat badan lahir normal. Kriteria eksklusi pada penelitian ini adalah bayi yang menderita kelainan kongenital dan bayi yang sedang dalam keadaan sakit.

Teknik pemilihan sampel dengan metode cluster random sampling. Alat yang digunakan dalam penelitian ini adalah timbangan badan bayi. Bahan yang digunakan dalam penelitian ini adalah kuesioner untuk mengetahui bayi mendapat ASI eksklusif+MPASI atau mendapat ASI noneksklusif+MP-ASI dan kurva pertumbuhan WHO.

Prosedur yang dilakukan dalam penelitian ini adalah peneliti dibantu kader menimbang badan bayi, lalu masukkan data ke dalam growth chart, setelah data dimasukkan ke dalam lembar growth chart lalu interpretasikan hasilnya. Analisis data dilakukan dengan menggunakan program statistical product and service solution (SPSS) pada derajat kepercayaan 95\% dan nilai $\mathrm{p} \leq 0,05$ dan analisis menggukanan Uji Fisher Exact dan Kruskal Wallis. Penelitian ini telah mendapat persetujuan etik oleh Komite Etik 
Penelitian Kesehatan Fakultas Kedokteran Universitas Islam Bandung dengan Nomor: 180/KomiteEtik.FK/ III/2018.

\section{Hasil Penelitian}

Hasil didapat dari penelitian analitik menggunakan pendekatan cohort untuk mengetahui pengaruh ASI eksklusif terhadap status gizi bayi usia 6-9 bulan. Subjek didapat sesuai dengan tujuan penelitian berjumlah 52 bayi dengan 27 bayi mendapat ASI eksklusif dan 25 bayi mendapat ASI noneksklusif yang telah memenuhi kriteria inklusi.

Tabel 1 Karakteristik Subjek Penelitian

\begin{tabular}{|c|c|c|}
\hline Karakteristik & $\begin{array}{c}\text { ASI } \\
\text { Eksklusif } \\
(\mathbf{n}=27) \\
\mathbf{n}\end{array}$ & $\begin{array}{c}\text { ASI Non- } \\
\text { eksklusif } \\
(n=25) \\
n\end{array}$ \\
\hline \multicolumn{3}{|l|}{$\begin{array}{l}\text { Usia awal mendapat MP- } \\
\text { ASI: }\end{array}$} \\
\hline$<6$ bulan & o & 4 \\
\hline$\geq 6$ bulan & 27 & 21 \\
\hline \multicolumn{3}{|l|}{$\begin{array}{l}\text { Kenaikan status gizi usia } 6 \\
-9 \text { bulan: }\end{array}$} \\
\hline tetap & 27 & 21 \\
\hline naik & o & 4 \\
\hline \multicolumn{3}{|l|}{ Pendidikan ibu: } \\
\hline SD & 10 & 7 \\
\hline SMP & 10 & 8 \\
\hline SMA & 5 & 6 \\
\hline Perguruan Tinggi & 2 & 4 \\
\hline \multicolumn{3}{|l|}{ Pekerjaan ibu: } \\
\hline Ibu rumah tangga & 26 & 9 \\
\hline $\begin{array}{l}\text { Lain-lain (wiraswasta, } \\
\text { buruh, pegawai swasta) }\end{array}$ & 1 & 16 \\
\hline \multicolumn{3}{|l|}{ Sosio-ekonomi keluarga: } \\
\hline >UMR ${ }^{8}(>\mathrm{Rp} 2.678 .028,98)$ & 13 & 19 \\
\hline$<\mathrm{UMR}^{8}(<\mathrm{Rp} 2.678 .028,98)$ & 14 & 6 \\
\hline
\end{tabular}

Berdasar atas hasil Tabel 1, kelompok bayi yang diberi ASI eksklusif dan yang noneksklusif pada pemberian awal MP-ASI pada umumnya usia di atas 6 bulan. Hanya 4 dari 25 bayi noneksklusif telah mendapat MP-ASI di bawah usia 6 bulan. Dari kedua kelompok tersebut kenaikan status gizi usia 6-9 bulan pada umumnya tetap. Pendidikan terakhir SD dan SMP ibu lebih banyak pada kelompok bayi yang mendapat ASI eksklusif.

Pekerjaan ibu sebagai ibu rumah tangga paling banyak pada kelompok bayi yang mendapat ASI eksklusif dibanding dengan kelompok noneksklusif. Sosio-ekonomi keluarga yang di bawah maupun yang di atas UMR pada kelompok bayi yang mendapat ASI eksklusif hampir sama banyak, pada kelompok bayi yang mendapatkan ASI noneksklusif paling banyak di bawah UMR.

Tabel 2 Pengaruh ASI Eksklusif+MP-ASI terhadap
Kenaikan Status Gizi

\begin{tabular}{lccc}
\hline & $\begin{array}{c}\text { Gizi } \\
\text { Tetap }\end{array}$ & $\begin{array}{c}\text { Gizi } \\
\text { Naik }\end{array}$ & Nilai p \\
\hline ASI Eksklusif + MP-ASI & 27 & 0 & 0,047 \\
ASI Noneksklusif + MP-ASI & 21 & 4 & \\
\hline
\end{tabular}

Berdasar atas Tabel 2 tidak didapatkan bayi yang mengalami kenaikan status gizi dalam kelompok ASI eksklusif+MP-ASI, berbeda dengan kelompok yang diberikan ASI noneksklusif+MP-ASI. Secara statistik antara kelompok bayi yang mendapat ASI eksklusif+MP-ASI dan ASI noneksklusif+MP-ASI dengan kenaikan status gizi terdapat pengaruh yang signifikan.

\section{Tabel 3 Pengaruh Karakteristik terhadap Kenaikan Status Gizi}

\begin{tabular}{|c|c|c|c|c|c|}
\hline \multirow{2}{*}{ Karakteristik } & \multicolumn{2}{|c|}{$\begin{array}{c}\text { ASI } \\
\text { Eksklusif }\end{array}$} & \multicolumn{2}{|c|}{$\begin{array}{c}\text { ASI } \\
\text { Noneksklusif } \\
\end{array}$} & \multirow{2}{*}{$\begin{array}{l}\text { Nilai } \\
\mathbf{p}\end{array}$} \\
\hline & $\begin{array}{c}\text { Gizi } \\
\text { Tetap }\end{array}$ & $\begin{array}{c}\text { Gizi } \\
\text { Naik }\end{array}$ & $\begin{array}{c}\text { Gizi } \\
\text { Tetap }\end{array}$ & $\begin{array}{c}\text { Gizi } \\
\text { Naik }\end{array}$ & \\
\hline Pekerjaan & & & & & 0,25 \\
\hline Ibu rumah tangga & 26 & o & 9 & o & \\
\hline $\begin{array}{l}\text { Lain-lain (wiraswasta, } \\
\text { buruh, pegawai } \\
\text { swasta) }\end{array}$ & 1 & o & 12 & 4 & \\
\hline Pendidikan & & & & & 0,19 \\
\hline $\mathrm{SD}+\mathrm{SMP}$ & 20 & o & 14 & 1 & \\
\hline SMA+Perguruan Tinggi & 7 & o & 7 & 2 & \\
\hline $\begin{array}{l}\text { Sosio-ekonomi } \\
\text { keluarga }\end{array}$ & & & & & 0,54 \\
\hline $\begin{array}{l}\text { UMR (Upah } \\
\text { Minimum Regional) } \\
\text { (>Rp2.678.028,98) }\end{array}$ & 13 & $\mathrm{O}$ & 15 & 4 & \\
\hline $\begin{array}{l}<\text { UMR (Upah } \\
\text { Minimum Regional) } \\
(<\mathrm{Rp} 2.678 .028,98)\end{array}$ & 14 & o & 6 & & \\
\hline
\end{tabular}

Dari Tabel 3 tidak didapatkan bayi yang mengalami kenaikan status gizi dalam kelompok ASI eksklusif, berbeda dengan kelompok yang ASI noneksklusif. Secara statistik tidak terdapat hubungan yang signfikan antara pekerjaan ibu, pendidikan ibu, dan sosio ekonomi keluarga dengan kenaikan status gizi dalam setiap kelompok.

Tabel 4 Kenaikan Rerata Berat Badan Bayi Usia 6-9 Bulan Tiap Bulan

\begin{tabular}{ccccc}
\hline \multirow{2}{*}{$\begin{array}{c}\text { Kenaikan } \\
\text { Berat Badan }\end{array}$} & \multicolumn{2}{c}{ ASI Eksklusif } & \multicolumn{2}{c}{$\begin{array}{c}\text { ASI } \\
\text { Noneksklusif }\end{array}$} \\
\cline { 2 - 5 } & Rerata & nilai p & Rerata & nilai p \\
\hline 7 bulan & 0,241 & 0,000 & 0,52 & 0,000 \\
8 bulan & 0,311 & 0,000 & 0,34 & 0,000 \\
9 bulan & 0,285 & 0,000 & 0,23 & 0,000 \\
\hline
\end{tabular}


Berdasar atas Tabel 4, kenaikan berat badan tiap bulannya pada kelompok bayi yang mendapat ASI eksklusif dan bayi yang mendapat ASI noneksklusif naik sangat signifikan.

\section{Pembahasan}

Status gizi sangat berpengaruh terhadap pertumbuhan dan perkembangan bayi. Berdasar atas hasil penelitian tidak didapatkan bayi yang mengalami kenaikan status gizi dalam kelompok ASI eksklusif, berbeda dengan kelompok yang ASI noneksklusif, tetapi secara statistik tidak bermakna. Hal ini dapat terjadi karena kandungan ASI sesuai dengan kebutuhan gizi bayi sehingga bayi yang mendapat ASI eksklusif tidak berisiko memiliki gizi lebih, sedangkan bayi yang mendapat ASI noneksklusif cenderung mendapat susu formula. Bayi yang mendapat susu formula berisiko lebih tinggi untuk mengalami obesitas pada masa bayi. ${ }^{9}$ Secara statistik didapatkan antara kelompok bayi yang mendapat ASI eksklusif+MP-ASI dan ASI noneksklusif+MP-ASI dengan kenaikan status gizi terdapat pengaruh yang signifikan. Hal ini sesuai dengan penelitian yang dilakukan oleh Maria $^{10}$ yang menyatakan bahwa terdapat hubungan antara ASI eksklusif +MP-ASI dan status gizi bayi usia 6-12 bulan .

Bayi dengan keadaan gizi yang lebih baik berkaitan erat dengan perilaku pemberian ASI, tetapi mereka yang sudah tidak diberi ASI lagi ternyata keadaan gizinya lebih rendah atau bahkan lebih. Sikap ibu dalam pemberian ASI eksklusif berpengaruh pada status gizi bayi, semakin positif sikap ibu dalam pemberian ASI eksklusif maka semakin baik pula status gizi bayinya. Pemberian MP-ASI yang tidak sesuai dengan usia dan kebutuhan bayi dapat menimbulkan dampak pada kesehatan dan status gizi bayi. ASI merupakan makanan yang higienis, murah, mudah diberikan, dan sudah tersedia bagi bayi.

Komposisinya yang dinamis dan sesuai dengan kebutuhan bayi menjadikan ASI sebagai asupan gizi yang optimal bagi bayi. ASI dan plasma memiliki konsentrasi ion yang sama sehingga bayi tidak memerlukan cairan atau makanan tambahan. Air susu ibu memiliki semua unsur yang memenuhi kebutuhan bayi akan gizi kecuali jika ibu megalami keadaan gizi kurang yang berat atau gangguan kesehatan lain. Komposisi ASI akan berubah sejalan dengan kebutuhan bayi. Bayi berusia 6-9 bulan pada penelitian ini sudah dipastikan mendapat MP-ASI.

Air susu ibu merupakan makanan yang bergizi yang sesuai dengan kebutuhan tubuh sehingga tidak memerlukan tambahan komposisi. Di samping itu, ASI mudah dicerna oleh bayi dan langsung terserap. Diperkirakan $80 \%$ ibu yang melahirkan ternyata mampu menghasilkan air susu dalam jumlah yang cukup untuk keperluan bayinya secara penuh tanpa makanan tambahan selama enam bulan pertama. Bahkan ibu yang gizinya kurang baik pun dapat menghasilkan ASI cukup tanpa makanan tambahan selama tiga bulan pertama. ${ }^{11}$ Jumlah ASI yang dikonsumsi termasuk energi dan zat gizi lainnya yang terkandung di dalam ASI sangat menentukan pertumbuhan dan perkembangan bayi.
Pada penelitian ini kenaikan berat badan dari usia 6 bulan ke-7 bulan, dari 7 bulan ke- 8 bulan, dan dari 8 bulan ke-9 bulan pada kelompok bayi yang mendapat ASI eksklusif maupun pada kelompok bayi yang mendapat ASI noneksklusif naik sangat signifikan, namun rerata secara keseluruhan data kenaikan berat badan tiap bulannya pada kelompok bayi yang mendapat ASI noneksklusif lebih tinggi dibanding dengan kelompok bayi yang mendapat ASI eksklusif. Sesuai dengan penjelasan sebelumnya, hal ini dapat terjadi karena bayi yang mendapat ASI noneksklusif ibunya memberikan susu formula dengan kandungan gizi susu formula lebih tinggi dibanding dengan kandungan gizi ASI. Formula susu sapi dibuat dari susu sapi skim yang komposisi nutriennya disusun ulang atau campuran susu sapi skim dan protein whey kasein susu sapi yang elektrolitnya sudah dikurangi. Lemak yang digunakan dalam formula bayi adalah campuran minyak tumbuhan, umumnya minyak kedelai, sawit, kelapa, jagung, dan minyak dari lemak hewan atau safflower.

Karbohidrat umumnya berupa laktosa, namun tersedia pula formula yang berbahan dasar susu sapi yang bebas laktosa. ${ }^{9}$ Bayi yang mendapat formula berisiko lebih tinggi untuk mengalami obesitas pada masa anak. Formula bayi berbahan dasar susu sapi pada penelitian ini digunakan sebagai pengganti ASI bagi bayi yang ibunya tidak dapat memberikan ASI dikarenakan bekerja atau pengeluaran ASI sedikit atau tidak ada sama sekali.

Gizi sangat berperan dalam tumbuh kembang anak. Tujuan pemberian gizi yang baik adalah mencapai tumbuh kembang anak yang adekuat. ${ }^{12}$ Terdapat beberapa faktor yang memengaruhi status gizi di antaranya faktor langsung dan tidak langsung. Faktor langsung yang memengaruhi status gizi ialah penyakit infeksi dan asupan makanan, sedangkan faktor tidak langsung antara lain ketahanan pangan di dalam keluarga, pola asuh, sanitasi lingkungan, akses terhadap pelayanan kesehatan, usia anak, jenis kelamin anak, tempat tinggal, pendidikan, dan pekerjaan orangtua. ${ }^{13}$ Pada penelitian ini faktor tidak langsung yang dibahas adalah karakteristik ibu seperti pendidikan ibu, pekerjaan ibu, juga karakteristik keluarga seperti sosio ekonomi keluarga.

Berdasar atas literatur, semakin tinggi tingkat pendidikan seseorang maka semakin mudah diberikan pengertian mengenai suatu informasi dan semakin mudah untuk mengimplementasikan pengetahuannya dalam perilaku khususnya dalam hal kesehatan dan gizi. Dengan demikian, pendidikan ibu yang relatif rendah juga akan berkaitan dengan sikap dan tindakan ibu dalam menangani masalah kurang gizi pada bayinya. Pada penelitian ini cenderung berkebalikan dengan teori tersebut, yaitu tingkat pendidikan ibu tidak berpengaruh signifikan terhadap kenaikan status gizi bayi pada kelompok bayi yang mendapat ASI eksklusif dan noneksklusif. Hasil penelitian ini sejalan dengan penelitian Nila Kesuma dkk. ${ }^{14}$ bahwa tidak ada hubungan bermakna antara tingkat pendidikan ibu dan kenaikan status gizi. Tingkat pendidikan ibu tidak berpengaruh terhadap status gizi bayi dimungkinkan karena semakin banyak informasi yang dapat diperoleh ibu dari berbagai sumber sehingga tidak harus melalui 
jalur formal ibu dapat mengaksesnya.

Ibu yang rajin membaca informasi tentang gizi atau turut serta dalam kegiatan penyuluhan gizi tentunya akan mampu menyajikan gizi yang sesuai dengan kebutuhan bayinya saat ini. Pada penelitian yang dilakukan Nilakesuma dkk. ${ }^{14}$ dinyatakan pula bahwa seseorang yang hanya tamat sekolah dasar akan berbeda pengetahuan gizinya dibanding dengan yang pendidikannya lebih tinggi. Namun, belum berarti seseorang yang hanya tamat sekolah dasar kurang mampu menyusun makanan yang memenuhi persyaratan gizi. Hal ini dikarenakan jika orang tersebut rajin membaca informasi tentang gizi atau turut serta dalam penyuluhan gizi bukan mustahil pengetahuan gizinya akan lebih baik. Hanya perlu dipertimbangkan seseorang yang memiliki tingkat pendidikan yang tinggi akan lebih mudah dalam menerima pesan dan informasi gizi. Pada penelitian ini yang diteliti adalah tingkat pendidikan yang telah ibu selesaikan secara formal, sedangkan pengetahuan ibu mengenai kesehatan tidak diteliti. Hal ini dapat menjadi salah satu faktor yang menyebabkan hasil penelitian tidak bermakna.

Menurut data Departemen Ketenagakerjaan Indonesia terdapat banyak perempuan yang bekerja saat ini, yaitu secara total sebesar $47,91 \%$. Perempuan yang bekerja di perkotaan sebanyak 44,47\%, sedangkan di perdesaan 51,10\%. Sementara itu, banyaknya perempuan sebagai pengangguran terbuka $3,48 \%$. Hal ini akan berpengaruh pada kondisi gizi balita yang dimiliki oleh perempuan yang bekerja. ${ }^{15}$ Namun, pada penelitain ini status pekerjaan ibu tidak berpengaruh signifikan terhadap kenaikan status gizi pada kelompok bayi yang mendapat ASI eksklusif dan ASI noneksklusif. Hal ini sama dengan hasil penelitian yang dilakukan oleh Rozali dkk. ${ }^{15}$ yang menyatakan hasil penelitiannya tidak ada peranan antara pekerjaan ibu dan status gizi bayi. Walaupun ibu yang bekerja berada di luar rumah selama bekerja, akan tetapi jika mempunyai pengetahuan yang cukup, ibu tersebut dapat mengatur waktu dalam mengasuh anaknya. Faktor lain yang mungkin terjadi adalah ibu yang bekerja mungkin menitipkan anaknya kepada nenek bayi atau pengasuh yang dapat memengaruhi status gizi bayi. Ibu yang bekerja akan mendapatkan pendapatan keluarga bertambah sehingga dapat memenuhi kebutuhan anaknya termasuk kebutuhan asupan makanan. Sebaliknya, keluarga dengan pendapatan terbatas kemungkinan besar akan kurang dalam memenuhi kebutuhan makanan walaupun ibunya bekerja terutama untuk memenuhi kebutuhan gizi bayi.

Status gizi pada masyarakat dipengaruhi oleh banyak faktor. Kondisi sosial ekonomi merupakan salah satu faktor penting yang memengaruhi status gizi. Bila kondisi sosio ekonomi baik maka status gizi diharapkan semakin baik. Status gizi bayi akan berkaitan erat dengan kondisi sosial ekonomi keluarga (orangtua). Menurut teori, jika suatu keluarga memiliki pendapatan yang besar serta cukup untuk memenuhi kebutuhan gizi anggota keluarga maka pemenuhan kebutuhan gizi pada bayi dapat terjamin. Sementara pendapatan yang rendah menyebabkan daya beli rendah sehingga tidak mampu membeli pangan dalam jumlah yang diperlukan dan pada akhirnya berakibat buruk terhadap status gizi bayi. ${ }^{16}$ Pada penelitian ini sosio ekonomi keluarga terhadap kenaikan status gizi di kelompok bayi yang mendapat ASI eksklusif dan noneksklusif tidak terdapat pengaruh yang signifikan. Hal ini sesuai dengan penelitian yang dilakukan oleh Rozali dkk. ${ }^{15}$ faktor yang dapat memengaruhi hasil penelitian ini di antaranya adalah ibu yang memiliki pendapatan yang tinggi kurang efisien dalam membelajakan makanan. Kemudian, ada juga ibu-ibu yang membeli pangan dengan jumlah yang sedikit sehingga berdampak pada kurangnya asupan pada balitanya. Faktor lain yang berpengaruh adalah jumlah anak di dalam satu keluarga. Pada keluarga yang memiliki anak banyak akan membutuhkan cadangan makanan yang lebih banyak bila dibanding dengan keluarga yang memiliki anak lebih sedikit sehingga sosio ekonomi keluarga yang tinggi pada keluarga yang memiliki banyak anak tidak akan berpengaruh pada status gizi. ${ }^{15}$ Keterbatasan penelitian ini di antaranya adalah pemilihan variabel untuk mengetahui status gizi bayi kemungkinan belum dapat menggambarkan secara keseluruhan permasalahan yang ada karena terdapat faktor lain yang berpengaruh terhadap status gizi pada bayi yang diberi ASI eksklusif+MPASI dan non eksklusif+MP-ASI, yaitu faktor tempat tinggal, pola asuh, sanitasi lingkungan, akses terhadap pelayanan kesehatan, jenis kelamin anak, jenis dan pola pemberian makanan pendamping ASI, dan riwayat penyakit infeksi yang tidak diteliti dalam penelitian ini.

\section{Simpulan}

Terdapat pengaruh ASI-eksklusif+MP-ASI terhadap status gizi bayi usia 6-9 bulan di Desa Sukawening Kecamatan Ciwidey Kabupaten Bandung.

\section{Ucapan Terima Kasih}

Ucapan terima kasih penulis sampaikan kepada seluruh ibu yang mengikuti penelitian ini dan kader Puskesmas Rawabogo di Desa Sukawening Kecamatan Ciwidey Kabupaten Bandung yang telah berpartisipasi dalam penelitian ini.

\section{Daftar Pustaka}

1. Yogi ED. Pengaruh pola pemberian ASI dan pola makanan pendamping ASI terhadap status gizi bayi usia 6-12 bulan. J Delima Harapan. 2014 Februari-Juli;2(1):14-8.

2. Fikawati S, Syafiq A. Kajian implementasi dan kebijakan air susu ibu eksklusif dan inisiasi menyusui dini di Indonesia. Makara Kes. 2010;14(1):17-24.

3. Susanto H, Wilar R, Lestari H. Faktor-faktor yang mempengaruhi pemberian susu formula pada bayi yang dirawat di ruang nifas RSUP. J e-clinic. 2015;3(1):161-8.

4. Lestari P, Kartini A. Hubungan praktik pemberian susu formula dengan status gizi bayi usia 0-6 bulan 
di Kecamatan Semarang Timur Kota Semarang. JKM e-journal. 2014 April;2:339-48.

5. Sakti RE, Hadju V, Rochimiwati SN. Hubungan pola pemberian mp-asi dengan status gizi anak usia 6-23 bulan di Wilayah Pesisir Kecamatan Tallo Kota Makassar tahun 2013. Makara Kes. 2013;1:1-3.

6. Mufida L, Widyaningsih TD, Maligan JM. Prinsip dasar makanan pendamping air susu ibu (MPASI) untuk bayi 6-24 bulan. Pangan Agroindustri. 2013;4:1646-1651.

7. Ratnaningsih E. Hubungan pemberian ASI eksklusif dan makanan pendamping ASI terhadap status gizi bayi 6-12 bulan. Kebidanan Panti Wilasa. 2011;2(1):1-7.

8. Agus P. Daftar lengkap UMK 27 kabupaten dan kota di Jawa Barat tahun 2018. Gajiumr. 2018;1(2):4.

9. Marcdante KJ, Kliegman RM, Jenson HB. Nutrisi pediatrik dan kelainan nutrisi pediatrik. Dalam: Tharmapalan S, penyunting. Nelson ilmu kesehatan anak esensial. Edisi ke-6. Singapore: Saunders Elsavier; 2013.

10. Maria I. Hubungan pemberian ASI eksklusif dengan status gizi bayi usia $6-12$ bulan di Polindes
Patranrejo Berbek Nganjuk. Hospital Majapahit. 2016;1(2):16-8.

11. Susilaningsih TI. Gambaran pemberian ASI eksklusif bayi 0-6 bulan. J Kes Masy Samigaluh II. 2013;2(8):81-9.

12. Lestari MU, Lubis G, Pertiwi D. Hubungan pemberian makanan pendamping ASI (MP-ASI) dengan status gizi anak usia 1-3 tahun di Kota Padang tahun 2012. J Kesehatan Andalas. 2012;3(2):188-90.

13. Putri SKD, Wahyono YMT. Teknologi intervensi kesehatan masyarakat. Media Litbangkes. 2013;23(3):110-21.

14. Nilakesuma A, Jurnalis YD, Rusjdi SR. Hubungan status gizi bayi dengan pemberian ASI ekslusif, tingkat pendidikan ibu dan status ekonomi keluarga di Wilayah Kerja Puskesmas Padang Pasir. J Kesehat Andalas. 2015;4(1):35-5.

15. Rozali NA, Subagyo B, Widhiyastuti E. Peranan pendidikan, pekerjaan ibu dan pendapatan keluarga terhadap status gizi balita di Posyandu Rw 24 dan 08 Wilayah Kerja Puskesmas Nusukan Kota Surakarta. J Kes Masy. 2016;3(2):12-3.

16. Putri RF, Sulastri D, Lestari Y. Faktor-faktor yang berhubungan dengan status gizi anak balita di Wilayah Kerja Puskesmas Nanggalo Padang. J Kesehat Andalas. 2015;4(1):254-61. 